\title{
The Growth of Brown Adipose Tissue in Cold-acclimatized Rats after Depletion of Mast Cell Histamine by Compound 48/80
}

\author{
Nelson L Daló/ ${ }^{+}$, Aura A López-Ortega, Haity Moussatché* \\ Unidad de Investigación en Ciencias Funcionales, Escuela de Ciencias Veterinarias, Universidad Centroccidental \\ Lisandro Alvarado, Barquisimeto, Venezuela *Departamento de Fisiologia e Farmacodinâmica, Instituto \\ Oswaldo Cruz, Av. Brasil 4365, 21045-900 Rio de Janeiro, RJ, Brasil
}

Cold acclimatization $\left(4-5^{\circ} \mathrm{C}\right)$ is accompanied by 2-3 fold increase of brown adipose tissue (BAT). This rapid growth of interscapular BAT was studied after histamine depletion. In control rats maintained at room temperature $\left(28 \pm 2^{\circ} \mathrm{C}\right.$ ) the BAT histamine content was $23.4 \pm 5.9$ (mean $\left.\pm S D\right) \mu g / g$ of tissue and cold acclimatization $\left(5 \pm 1{ }^{\circ} \mathrm{C}\right)$ produced a significant increase of BAT weight, but reduced the histamine content to $8.4 \pm 1.9 \mu \mathrm{g} / \mathrm{g}$. The total weight of BAT after 20 days of acclimatization was unaffected by depletion of histamine due to compound 48/80. The low level of histamine in BAT of cold acclimatized rats could be due to a fast rate of amine utilization; alternatively an altered synthesis or storage process may occur during acclimatization.

Key words: cold acclimatization - brown adipose tissue - histamine - tissue growth

Homeothermic animals have the capacity to maintain body temperature by a variety of physiological responses, the most important of which is to enhance nonshivering thermogenesis (NST). The rapid growth of the brown adipose tissue (BAT) appears to play a crucial role in NST and is thought to be mainly regulated by sympathetic noradrenaline (Rothwell \& Stock 1985, Géloën et al. 1992) as well as other hormonal factors like thyroidal, adrenocortical and pancreatic hormones (Kuroshima et al. 1984, Howland \& Bond 1987).

Neurotransmitters that promote cell proliferation may do so by inhibiting adenylcyclase or by activating phospholipase C (PLC); these include 5-HT, adenosine (A1 receptors), norepinephrine (alpha-adrenergic receptors) and acetylcholine (muscarinic receptors) (for review see Lauder 1993). There are several reports that elevated level of histamine and its synthesizing enzyme are associated with rapid tissue growth (Kahlson \& Rosengren 1968). Considering that activation of $\mathrm{H}_{1}$ receptors results in a potent activation of PLC leading to phosphoinositide breakdown and subsequent intracellular $\mathrm{Ca}^{2+}$ mobilization (Johnson et al. 1990, Tilly et al. 1990), this subtype of histamine receptors is an attractive candidate for mediating cell growth.

${ }^{+}$Corresponding author. Fax +58-51-425989

Received 22 April 1997

Accepted 24 September 1997
Although the role of histamine in thermoregulation in the mammalian brain has been the focus of a number of investigations (Schwartz et al. 1991), no data exist in relation to the possible participation of histamine in promoting the hyperplasia of BAT in nonhibernating mammals submitted to acclimatization. The aim of this study was to determine whether normal growth of BAT takes place under condition of histamine depletion by compound 48/80.

\section{MATERIALS AND METHODS}

Adult female Sprague Dawley rats weighing 180-200 g raised in the Animal Facilities of Centroccidental University, were used. Each animal was caged separately and fed with commercial rat pellets. Four groups of animals were randomly chosen. Group A was kept at room temperature $\left(28 \pm 2{ }^{\circ} \mathrm{C}\right)$ as well as group $\mathrm{B}$, but the latter was pretreated with compound $48 / 80$. Groups $\mathrm{C}$ and $\mathrm{D}$ were acclimatized at $5 \pm 1^{\circ} \mathrm{C}$ for a period of 20 days, but $\mathrm{C}$ was pretreated with compound $48 / 80$.

Depletion of histamine - The histamine-liberator compound 48/80 (Sigma, St. Louis, MO) was dissolved in $0.85 \%$ saline and injected intraperitoneally (i.p.) at an initial dose of $1 \mathrm{mg} / \mathrm{kg}$. The following day the dose was increased to $2 \mathrm{mg} / \mathrm{kg}$; two days later animals were injected with $3 \mathrm{mg} / \mathrm{kg}$ and three days later with $4 \mathrm{mg} / \mathrm{kg}$ until a dose of $5 \mathrm{mg} /$ $\mathrm{kg}$ was reached the 11th day. This chronic dosage of $5 \mathrm{mg} / \mathrm{kg}$ was continued every 5 days for 1 month. Treatment regime was maintained during the 20 
days of acclimatization. Control groups (A at $28^{\circ} \mathrm{C}$ and $\mathrm{D}$ at $5^{\circ} \mathrm{C}$ ) received the same volume of vehicle.

Histamine bioassay - Animals were decapitated and the interscapular BAT was carefully dissected, cleaned of other surrounding tissue, weighed and homogenized in ice-cold $0.04 \mathrm{M} \mathrm{HCl}$. The homogenized tissue was heated for 1 min using a boiling bath and then centrifuged at $1000 \mathrm{~g}$ for $20 \mathrm{~min}$. The supernatant was transferred to a glass tube and $\mathrm{pH}$ adjusted to 7.0-7.4 using $\mathrm{NaHCO}_{3}$. Histamine activity was estimated using the isolated guineapig ileum preparation bathed in atropinised $(0.1$ $\mathrm{mg} / \mathrm{l}$ ) Tyrode's solution, bubbled with $95 \% \mathrm{O}_{2}-5 \%$ $\mathrm{CO}_{2}$. Temperature of bath was maintained at $35^{\circ} \mathrm{C}$ to decrease even more spontaneous motility of isolated preparation (Vugman \& Rocha e Silva 1964). Data were analyzed using Student's "t" test and a $\mathrm{p}<0.01$ was considered as significant.

\section{RESULTS}

An acclimatization period of 20 days was enough to induce a significant growth of interscapular BAT in the group D, when compared to the respective control maintained at $28^{\circ} \mathrm{C}$; moreover, the growth of BAT was also higher in the experimental group treated with compound 48/80 (Fig. 1A) indicating that pretreatment with the histamine depletor did not alter the total weight of BAT reached after long term cold-exposure.

In animals kept at room temperature (group A) the content of histamine in BAT was $23.4 \pm 5.9$ (mean \pm SD) $\mu \mathrm{g} / \mathrm{g}$ of tissue, amount that was easily extracted and estimated using conventional bioassay. Cold acclimatization reduced significantly the histamine content in BAT $(8.4 \pm 1.9 \mu \mathrm{g} / \mathrm{g}$ ) (Fig. 1B). Furthermore, treatment with compound 48/ 80 reduced $76 \%$ BAT histamine content when rats were kept at room temperature, and this reduction was also significant $(60 \%)$ when animals were cold-acclimatized (Fig. 1B). However, in spite of the amine depletion the BAT hyperplasia occurred and animals were able to survive the long cold exposure and they appeared normal with no signs of ataxia or motor impairments even under continuous high dose of compound 48/80.

The most interesting finding here reported was the low BAT histamine content found in cold-acclimatized rats, amount that was even lower after treatment with compound 48/80 (Fig. 1B).

\section{DISCUSSION}

In our laboratory we have routinely used a protocol of cold acclimatization in rodents to investigate its protective effect against fatty liver inducing agents (López-Ortega et al. 1993). When rats are cold acclimatized for a period of 20 days a strik-
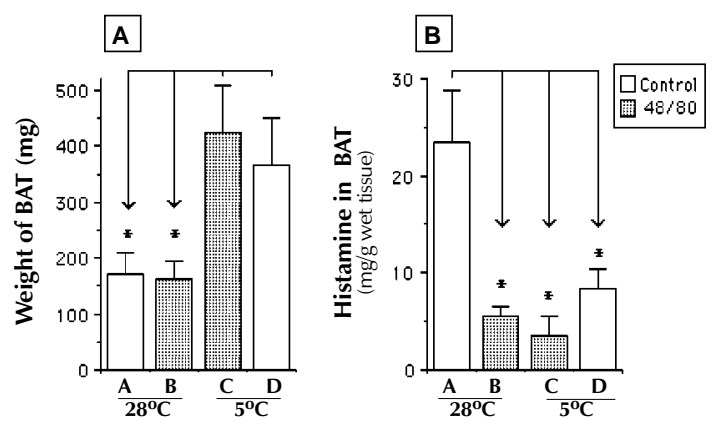

Effect of cold acclimatization on the total weight (A) and the histamine content in BAT (B) of treated and non-treated rats. Data are the mean numbers of 8 to 10 animals $\pm S D *$ represent a $\mathrm{p}<0.01$. Arrows indicate the comparisons between experimental groups that are statistically different. Temperature is indicated bellow horizontal bars.

ing observation is the rapid growth of interscapular BAT. No previous data exist in relation to the possible mediation of histamine in the rapid growth of BAT neither the alteration of its development after chronic treatment with histamine antagonists.

In the 1960s a number of investigators led by Kahlson and Rosengren (1968) introduced the concept that newly formed (nascent) histamine as a consequence of elevated histidine decarboxylase activity, plays a role in rapid tissue growth. Although the precise link has not been elucidated, recent works in relation to the mechanism of histamine as a growth factor (Tilly et al. 1990, Johnson et al. 1990, Van der Ven et al. 1993) excited us to report this study. This non-mast-cell pool of histamine has a more rapid turnover rate and it acts at the site, or in the cell, where it is formed (Kahlson \& Rosengren 1968); however, most of the histamine synthesized in the body is stored in mast cells being compound $48 / 80$ an effective agent able to release this pool (Chakravarty 1990).

Although compound $48 / 80$ is considered an effective histamine releaser, it is not specific. In rodents, 5-HT contained in mast cells is depleted by compound 48/80 (Moran et al. 1962). It is also a well known calmodulin and protein kinase $\mathrm{C}$ antagonist (Chakravarty 1992). In general, calmodulin antagonists are antiproliferative and carcinostatic, instead of tissue growth promoting agents (MacNeil et al. 1988).

One approach to study the role of histamine in tissue growth is to determine the histamine-forming capacity (HFC) of that specific tissue; however, this technique may be useless when compound $48 / 80$ is used because it increases HFC in some tissues (Kahlson \& Rosengren 1965). This effect explains why in the skin after the enhance- 
ment of HFC by compound 48/80, the rate of healing is augmented instead of retarded (Kahlson \& Rosengren 1965). Althought in BAT, this effect has not been determined yet, it is likely that the HFC may be also enhanced as a result of treatment with this polyamine. That led us to determine the histamine content instead of the HFC.

The values of histamine content in BAT in normal rats is similar to the histamine level reported in the liver capsule, lungs and skin in the same species and larger than that reported in many other living tissues (Vugman \& Rocha e Silva 1964); but, no study has been conducted to clarify the reason of such large amount of this amine in a tissue that is clearly involved in NST. Such large amount of histamine in BAT allows its estimation using a biological assay that is still considered an inexpensive and effective method for histamine determination (Nannaioni 1991), but currently it is now been replaced by state-of-the-art chromatographic techniques that are far more reliable but also expensive.

This work presents evidences that the concentration of histamine in BAT during NST is clearly low. It is unlikely that it is due to a histamine release process to the general circulation similar to the reported in acute hypothermia in which this vasoactive amine is associated with progressive hypotension, hypovolemia and hemoconcentration (Rink 1972). Alternatively, it is possible that this endogenous substance was used in a more physiological mechanism explaining the increased capacity of cold-acclimated rat: a rapid hyperplasia of BAT necessary to respond calorigenically to the stressing experimental situation.

In conclusion, this is the first work which studied a possible relationship between histamine and the growth of BAT. The most interesting result concerns with the significant low histamine content found in the BAT in animals submitted to cold acclimatization, amount that was even lower after treatment with compound 48/80, suggesting indirectly that acclimatization by itself has either enhanced the rate of histamine utilization or altered some mechanisms of amine synthesis or storage.

\section{REFERENCES}

Chakravarty N 1990. Mechanism of histamine secretion. Agents Actions 30: 5-12.

Chakravarty N 1992. The roles of calmodulin and protein kinase $\mathrm{C}$ in histamine secretion from mast cells. Agents Actions 36: 183-191.

Géloën A, Collet AJ, Bukowiecki LJ 1992. Role of sympathetic innervation in brown adipocyte proliferation. Am J Physiol 263: R1176-R1181.

Howland RJ, Bond KD 1987. Modulation by insulin and glucagon of nor adrenaline-induced activation of iso- lated brown adipocytes from the rat. Eur J Biochem 169: 155-166.

Johnson CL, Johnson CG, Bazan E, Garver D, Gruenstein E, Ahluwalia M 1990. Histamine receptors in human fibroblasts: inositol phosphates, $\mathrm{Ca}^{2+}$ and cell growth. Am J Physiol 258: C533-C543.

Kahlson G, Rosengren E 1965. Histamine. Annu Rev Pharmacol 5: 305-320.

Kahlson G, Rosengren E 1968. New approaches to the physiology of histamine. Physiol Rev 48: 155-196.

Kuroshima A, Yahata T, Habara Y, Ohno T 1984. Hormonal regulation of brown adipose tissue-with special references to the participation of endocrine pancreas. J Therm Biol 9: 81-85.

Lauder JM 1993. Neurotransmitter as growth regulatory signals: role of receptors and second messengers. Trends Neurosci 16: 233-239.

López-Ortega A, Carmona CA, Moussatché H 1993. On the mechanism of protective action of cold acclimatization against carbon tetrachloride- and ethionineinduced fatty liver. Mem Inst Oswaldo Cruz 88: 313331.

Moran NC, Uvnäs B, Westerholm B 1962. Release of 5hydroxytryptamine and histamine from rat mast cells. Acta Physiol Scand 56: 24-41.

MacNeil S, Griffin M, Cooke AM, Pettett NJ, Dawson RA, Owen R, Blackburn GM 1988. Calmodulin antagonists of improved potency and specificity for use in the study of calmodulin biochemistry. Biochem Pharmac 37: 1717-1723.

Nannaioni PF 1991. Current techniques of histamine determination: B. Bioassays, p. 3-8. In B Uvnäs, Histamine and Histamine Antagonists, SpringerVerlag Berlin Heidelberg New York, (Handbook of Experimental Pharmacology, Vol. 97).

Rink RD 1972. Mast cells, compound 48/80 and prolonged hypothermia in the rat. Am J Anatomy 133: 379-386.

Rothwell NJ, Stock MJ 1985. Biological distribution and significance of brown adipose tissue. Comp Biochem Physiol 82A: 745-751.

Schwartz J, Arrang J, Garbarg M, Pollard H, Ruat M 1991. Histaminergic transmission in the mammalian. Brain Physiol Rev 71: 1-51.

Tilly BC, Tertoolen LGJ, Remorie R, Ladoux A, Verlaan I, Laat SW, Moolenaar WH 1990. Histamine as a growth factor and chemoattractant for human carcinoma and melanoma cells: Action though $\mathrm{Ca}^{2+}$ mobilizing $\mathrm{H}_{1}$ receptors. J Cell Biol 110: 1211-1215.

Van Der Ven LTM, Prinsen IM, Jansen GH, Roholl PJM, Defferrari R, Slater R, Den Otter W 1993. Growth of cultured human glioma tumor cells can be regulated with histamine and histamine antagonists. $\mathrm{Br} J$ Cancer 68: 475-483.

Vugman I, Rocha e Silva M 1964. Biological determination of histamine in living tissue and body fluids, p. 81-115. In M Rocha e Silva, Histamine and Antihistaminics, Springer-Verlag Berlin Heidelberg New York, (Handbook of Experimental Pharmacology, Vol. 18/1). 
